\title{
Effects of additional fitness program on body composition and general motor skills in overweight children of school age
}

\author{
Miloš Milošev 1 \\ Ivana Đuričićć \\ Dušan Mitić ${ }^{1}$ \\ 1Faculty of sport and physical education, \\ University of Belgrade, Blagoja Parovića 156 \\ 11030 Belgrade, Serbia \\ 2School of Pharmacy, University of Belgrade, \\ Vojvode Stepe 450, 11221 Belgrade, Serbia \\ Rad primljen: 03.10.2015.
}

\begin{abstract}
Physicalactivity, health and quality of life are closely interconnected. The human body was designed to move and therefore needs regular physical activity in order to function optimally and avoid illness.

The aim of this research was to explore the differences in body composition and motor abilities after applying additional fitness program during 8 consecutive weeks and appropriate diet regime in overweight children of school age. A total of 12 boys were enrolled into the study. They were overweight basketball players with average body mass index $26.6 \pm 4.2$ and age $11.4 \pm 0.5$. Body composition was tested by bioelectrical impedance, while basic motor tests were used for physical abilities (Cooper test, strength tests and bent over test). All measures were done before and after 8 weeks of fitness program.

Additional program of training and diet regime influenced statistically significant differences in all measured anthropometric parameters (body height, body weight, body mass index, amount of fat, amount of muscles, $p<0.05$ ), except in basal metabolic rate.

After two months of training, subjects also showed statistically significant improvement in all tested motor abilities $(p<0.05)$.
\end{abstract}

Keywords: body composition, motor abilities, obese, fitness program, healthy diet

\section{INTRODUCTION}

According to the World Health Organization (WHO) [1], every year at least 1.9 million people worldwide die from lack of physical activity. Lack of physical activity is closely associated with the emergence of non-communicable diseases such as diabetes, cardiovascular diseases and obesity. Hypokinesia and obesity are the diseases of modern world, and persons under stress, adolescents, children and older people are particularly vulnerable [2]. Obesity could be defined as an excessive accumulation of fat, which may lead to serious health problems and a series of complications [3]. In accordance with the guidance documents of the WHO, the European Union and its Member States recommend a minimum of 60 minutes of daily moderate-intensity physical activity for children and young people [4].

The aim of this research was to apply additional fitness programs and appropriate diet in overweight and obese school children in order to reduce the negative phenomena of obesity and improve their body composition and sports performance. The training program was focused on losing fat, increasing muscle mass and development of general motor skills for a period of 8 weeks.

\section{MATERIAL AND METHODS}

This research was experimental study without a control group. More specifically, it was quantitative research which used descriptive (basic indicators measuring morphological characteristics and motor abilities of subjects) and comparative methods (detection of differences in anthropometric parameters and motor ability level by using T-test).

A total of 12 boys were enrolled into the study. They were overweight $(n=10)$ and obese $(n=2)$ basketball players with average body mass index $26.6 \pm 4.2$ and age $11.4 \pm 0.5$. Subjects were tested by bioelectrical impedance $[3,5,6,7,8]$ (body's composition parameters) and basic battery of tests for physical abilities (Cooper test, strength tests and bent over test)[9].After the initial tests, training program was performed during 8 consecutive weeks. It was aimed to improve body composition of subjects, and the basic physical skills such as endurance, strength and flexibility. Also, dietary advice was given to the children and their parents toward adjusted diet with reduced intake of energy, sugar and saturated fats, and increased intake of protein and complex carbohydrates. Recommended calorie intake was based on data from basal and rest metabolic rates. Carbohydrates were recommended in morning hours, intake of protein almost right after training sessions, and meals after $10 \mathrm{am}$ were avoided. Except protein meals after trainings, any other food was avoided in next several hours. Trainings were in aerobic intensity zone, which included running and walking. Main part of the training was in zone between $55 \%$ and $70 \%$ of maximum heart rate. Also, training program contained strength and exercise for increasing muscle mass, improvements of flexibility and speedy recovery. The children were tested again after completing the fitness program. 
All tests were done in special laboratory for anthropometric measurements at Faculty of sport and physical education in Belgrade and several gym centers.

The results are presented as means \pm SD. Value $\mathrm{p}<0.05$ was considered significant. The T-test was used to determine whether differences in the body composition and physical abilities before and after training program were significant.

\section{RESULTS AND DISCUSSION}

Based on the data in Table 1, the average age of subjects was 11.4 , the average height was 157.6 $\mathrm{cm}$, while the average weight was $58.7 \mathrm{~kg}$.

It was also noted that the average value of the body mass index was 26.6, the amount of fat 21 $\mathrm{kg}$, while the average percentage of fat was 36.3. Average value of muscle mass was $20.3 \mathrm{~kg}$, while the average of basal metabolic rate was $1322 \mathrm{kcal}$. The maximum value of fat content was $46 \%$, and the lowest $21 \%$ of total body weight. It was shown that the greatest amount of muscle mass was 30.1 $\mathrm{kg}$, and the lowest one was $15.2 \mathrm{~kg}$. The value of the basal metabolic rate was in the range of 1045 to $1658 \mathrm{kcal}$. Coefficient of variation (CV) for all parameters was below $30 \%$, which indicates that the group was relatively homogenous.

Table 2 shows parameters of physical abilities before the beginning of applied fitness program.

The average distance traveled meters in a Cooper test was 1800 , while the range of values was between 1705 and 2034 meters. The result for coefficient of variation $(4.9 \%)$ confirms very good homogeneity of group. On the other hand, assay for flexibility extensors (Bent-over), showed that tested boys were very different dynamically, i.e. mobile. The average value was $6 \mathrm{~cm}$, ranged from 1 to 31 . Therefore, the variability of results was extremely high (coefficient of variation was 151.8), which showed that the group was not homogeneous with respect to this physical ability test. On the holding endurance test (Pull-up hold), coefficient of variation was also high $(67.4 \%)$, and group was not homogeneous. Coefficient of variation for all other assays was below $30 \%$.

After two months of training program, all subjects were retested. Data is shown in Table 3.

As far as body mass index is concerned, the average value after two months of fitness program decreased by $14.3 \%$. The average value for body fat also decreased (by $7 \%$ ) at the end of the study. Mean value for the amount of muscles or lean body mass was $\%$ higher comparing to previous result. The values for basal metabolism were in the range of 1045 to $1574 \mathrm{kcal}$. Values for coefficient of variation showed that all parameters were fewer than 30, which means that group was relatively homogeneous across all measured categories.

Re-test of physical abilities were done only a few days after the measurement of body composition. The same tests were determined as in a previous stage: the assessment of basic endurance (Cooper test), tests to assess the strength (holding endurance, lying-sit in 30 seconds, stretching back for 30 seconds, jump out of the place), and test to assess flexibility (deep forward bent test). Data are shown in Table 4.

The values for Cooper test and Long jump assay increased by $12 \%$ during the 8 weeks of fitness program. The average values for the push-ups on bench and pull up hold tests increased by $54 \%$ and $52 \%$. Higher values were also found for Crunches

Table 1. Characteristics of the study group at baseline

\begin{tabular}{|l|c|c|c|}
\hline Parameters & Means \pm SD & Range & CV (\%) \\
\hline Age $(\mathrm{y})$ & $11.4 \pm 0.5$ & $10.8-12.3$ & 4.4 \\
\hline Body weight $(\mathrm{kg})$ & $58.7 \pm 11.9$ & $40.5-79$ & 20.4 \\
\hline Height $(\mathrm{cm})$ & $157.6 \pm 7.8$ & $147.7-175.6$ & 4.9 \\
\hline BMI $\left(\mathrm{kg} / \mathrm{m}^{2}\right)$ & $26.6 \pm 4.2$ & $18.3-31.3$ & 15.7 \\
\hline Body fat $(\mathrm{kg})$ & $21 \pm 6.3$ & $9.2-29.6$ & 29.8 \\
\hline Body fat $(\%)$ & $36.3 \pm 7.1$ & $21-46$ & 23.7 \\
\hline Muscle mass $(\mathrm{kg})$ & $20.3 \pm 4$ & $15.2-30.1$ & 19.8 \\
\hline Basal metabolism (kcal) & $1322 \pm 217.3$ & $1045-1658$ & 17.2 \\
\hline
\end{tabular}

Table 2. Results of physical abilities in tested group before fitness program

\begin{tabular}{|l|c|c|c|}
\hline Assays & Means \pm SD & Range & CV (\%) \\
\hline Cooper test $(\mathrm{m})$ & $1800 \pm 88.6$ & $1075-2034$ & 4.9 \\
\hline Push-ups on bench & $8.3 \pm 2.4$ & $6-13$ & 28.2 \\
\hline Pull-up hold (seconds) & $5.4 \pm 3.6$ & $1.9-14.3$ & 67.4 \\
\hline Crunches (30 seconds) & $11.7 \pm 1.4$ & $10-14$ & 11.6 \\
\hline Back extensions (30 seconds) & $16.4 \pm 1.9$ & $13-19$ & 11.5 \\
\hline Long jump (cm) & $114 \pm 17.4$ & $95-145$ & 15.3 \\
\hline Bent-over (cm) & $6 \pm 9.1$ & $1-31$ & 151.8 \\
\hline
\end{tabular}


and Back extensions after the intervention period ( $23 \%$ and $7 \%$, respectively). At the end of the study, the highest increase was measured for bentover assay $(323 \%)$.

It was shown that 2 months of fitness program were useful in improving anthropometric parameters and physical performance (Table 5).

Additional program of training and diet regime influenced statistically significant differences in all measured anthropometric parameters (body height, body weight, BMI, amount of fat, percentage of fat, amount of muscles parameters, $\mathrm{p}<0.05)$, except in basal metabolic rate.
After two months of training, subjects also showed statistical significant improvement in all tested motor abilities $(p<0.05)$.

Regular, well-designed and planned training sessions, based on the general laws of development of the aforementioned physical abilities that are important for public health (and thus the control of body weight), manifested their influence on basic endurance, explosive and repetitive force and passive flexibility. Running in an aerobic intensity zone created on the basis of recommendations of a doctor Kenneth Cooper, resulted in a general improvement of aerobic endurance[10].Additional work in a recovery intensity zone, contributed above

Table 3. Results of anthropometric measure after 2 months of fitness program

\begin{tabular}{|l|c|c|c|}
\hline Parameters & Means \pm SD & Range & CV (\%) \\
\hline Age $(\mathrm{y})$ & $11.5 \pm 0.5$ & $10.8-12.3$ & 4.4 \\
\hline Body weight $(\mathrm{kg})$ & $57.4 \pm 12$ & $40.5-79.3$ & 20.9 \\
\hline Height $(\mathrm{cm})$ & $157.9 \pm 8.2$ & $147.7-177.1$ & 5.2 \\
\hline BMI $\left(\mathrm{kg} / \mathrm{m}^{2}\right)$ & $22.8 \pm 2.8$ & $17.9-26.8$ & 12.5 \\
\hline Body fat $(\mathrm{kg})$ & $19.5 \pm 5.5$ & $9.2-25.8$ & 28 \\
\hline Body fat $(\%)$ & $34 \pm 7.4$ & $18.8-44.2$ & 21.9 \\
\hline Muscle mass $(\mathrm{kg})$ & $20.7 \pm 4.2$ & $16.1-30.7$ & 20.4 \\
\hline Basal metabolism (kcal) & $1262 \pm 152.6$ & $1045-1574$ & 12.1 \\
\hline
\end{tabular}

Table 4. Results of physical abilities in tested group after 2 months of fitness program

\begin{tabular}{|l|c|c|c|}
\hline Assays & Means \pm SD & Range & CV (\%) \\
\hline Cooper test $(\mathrm{m})$ & $2020.5 \pm 201.7$ & $1780-2456$ & 10 \\
\hline Push-ups on bench & $12.8 \pm 5.5$ & $7-28$ & 43.2 \\
\hline Pull-up hold (seconds) & $8.2 \pm 6.8$ & $2.4-12.6$ & 82.1 \\
\hline Crunches (30 seconds) & $14.4 \pm 1.5$ & $12-16$ & 10.4 \\
\hline Back extensions (30 seconds) & $17.5 \pm 2$ & $14-20$ & 11.6 \\
\hline Long jump (cm) & $128.1 \pm 23$ & $101-162$ & 18 \\
\hline Bent-over $(\mathrm{cm})$ & $19.4 \pm 9.8$ & $2-33$ & 50.2 \\
\hline
\end{tabular}

Table 5. The estimates of change between values before and after fitness program

\begin{tabular}{|l|c|c|}
\hline Parameters & Difference & P value \\
\hline Body weight $(\mathrm{kg})$ & -1.5 & $<0.01^{* *}$ \\
\hline Height $(\mathrm{cm})$ & 0.4 & $<0.05^{*}$ \\
\hline BMI $\left(\mathrm{kg} / \mathrm{m}^{2}\right)$ & -2.1 & $<0.01^{* *}$ \\
\hline Body fat $(\mathrm{kg})$ & -1.5 & $<0.001^{* * *}$ \\
\hline Body fat $(\%)$ & -2.3 & $<0.001^{* * * *}$ \\
\hline Muscle mass $(\mathrm{kg})$ & 0.6 & 0.07 \\
\hline Basal metabolism (kcal) & -60.6 & $<0.001^{* * *}$ \\
\hline Assays & & $<0.001^{* * *}$ \\
\hline Cooper test (m) & 220 & $<0.05^{*}$ \\
\hline Push-ups on bench & 5 & $<0.001^{* * *}$ \\
\hline Pull-up hold & 2.8 & $0.05^{*}$ \\
\hline Crunches (30 seconds) & 3 & $<0.001^{* * *}$ \\
\hline Back extensions (30 seconds) & 1 & $<0.01^{* *}$ \\
\hline Long jump (cm) & 13 & \\
\hline Bent-over (cm) & 5 & \\
\hline *Novo statističke značajnosti & & \\
\hline
\end{tabular}


all to fat burning (impact on body composition). Strength endurance exercises, its isometric contractions influenced the development of static muscle strength, and thus the improvement of results in the holding endurance test. Additional exercises, such as squats and lunges, influenced the development of repetitive and explosive strength of muscles. This is the best demonstrated in the tests of crunches for 30 seconds, back extensions, pushups on the bench and long jump.

The application of flexibility exercises, influenced the development of passive and general flexibility (flexibility of the muscles of the lower back and hamstrings). In this way, improved results in bent-over re-test (increased mobility of the lower part of body), were achieved by additional training program.

All subjects during the program performed major part of physical exercise in an aerobic intensity zone, primarily in the range of $55 \%$ to $70 \%$ of maximum heart rate, which is recommended as an excellent area for using fat as an energy source [9]. Post-exercise in this intensity zone with appropriate enhanced duration also contribute to fat burning. Then, the endurance exercise contributed to strengthen the muscles of the body, or increasing muscle mass in subjects. Increased muscle mass associates to the increased basal metabolic rate. On the other hand, the fat loss and increase in muscle mass can be directly linked to the implementation of appropriate exercise, improving body composition in a whole. Correction of dietary regime related to reduced intake of fat and simple carbohydrates, contributed to rapid weight loss, while increased intake of proteins in diet contributed to the increased muscle mass. Statistically insignificant changes of basal metabolic rate can be explained by duration of training period and relatively small, although significant, increase in muscle mass.

\section{CONCLUSION}

In conclusion, the results of the present study indicate that the additional fitness program if applied even for a moderate period of time can be used for improvement of the body composition and general motor skills in overweight children of school age.

\section{REFERENCES}

1. Jovanović R, Nikolovski D, Radulović O, Novak $S$. Influence of physical activity on nutritional status of preschool children. Med J . 2010; 47 (2): 62-68.

2. Mitić D, Stojiljković S. Fitness index and maximal oxygen uptake among people with active lifestyle in Serbia.10th Annual congress"European College of Sport Science". Belgrade. Serbia. 2005; 370-371.

3. Ostojić $S$, Stojanović $M$, Stojanović $V$, Marić J, Njaradi N. Correlation between Fitness and Fatness in 6-14-year Old Serbian School Children. Journal of Health, Population \& Nutrition. 2011; 1 (29): 53.

4. WorldHealthOrganization. "Globalrecommendations onphysicalactivity for health", 2010.

5. Morrow JR, Jackson AW, Disch, JG, Mood DP. Measurment and Evaluation in Human Perfomance. Human Kinetics 2005; Champaign. IL.

6. Steven B, Heymsfield Wang. Human body composition advances in models and methods. Obesity Research Center Department of Medicine. St. Luke's-Roosevelt Hospital Center. Columbia University College of Physicians and Surgeons New York. New York. 1997; 1 (17):527-58.

7. Forbes GB. Simon W, Amatruda JM.Is bioimpedance a good predictor of body somposition change? Am. J. Clin. Nutr. 1992; 1 (56): 4-6.

8. Wang M, Pierson R, Heymsfield Steven.Five level model: new approach to organizing body composition research.Obesity Research Center, Department of Medicine, St. Luke's-Roosevelt Hospital Center, Columbia University College of Physicians and Surgeons. New York. New York 1992; 13 (1): 58-65.

9. Stojiljković S, Mitić D. Promene telesnog sastava rekreativaca nakon osmonedeljnog treninga aerobne izdržljivosti. Zbornik sažetaka"Prvi srpski kongres pedagoga fizičke culture \& 2nd FIEP European congress". Vrnjačka Banja. Srbija. 2004; 204-205.

10. Cooper, KH. Aerobics Program For Total WellBeing. Exercise, Diet, And EmotionalBalance. Bantam. 2013. 